\title{
13 New science in the old tongue
}

Auch Ansätze zur Mathematisierung in pythagoräischer Tradition haben wir bereits kennengelernt, so daß die Annahme, wonach die naturwissenschaftliche Methodologie in der Neuzeit blitzartig und wie eine neue Offenbarung der Menschen einsetzt, heute fragwürdig erscheint.

'We have also encountered approaches to mathematisation in the Pythagorean tradition, so that the assumption that scientific methodology in modern times begins in a flash and like a new revelation of mankind seems questionable today.'

Mainzer (1988: 69)

\$1 Reference is often made to a Scientific Revolution in the later sixteenth and seventeenth centuries that is seen as the foundations of modern science or even the beginning of 'true' science in general. ${ }^{1}$ The concept of such a revolution goes back to Alexandre Koyré (1939), who tried to show that the focus of natural science changed radically in this time, leading to modern science - that, using later Kuhnian terminology, a new paradigm arose. Koyré later claimed that Galileo's quantitative approach to science was completely new, and that, therefore, in a certain sense science proper begins only in the seventeenth century. ${ }^{2}$ Lloyd reviews this thesis in detail and refutes it, pointing out that, indeed, in some cases the Platonic 'search for exactness led not to Koyré's "universe of precision" but to spurious quantifications and ad hoc numerological elaborations'. ${ }^{3}$ It would seem that this 'revolution' in natural science was not so much based on new approaches or theories but more on a more strictly empirical approach and significant advances in mathematics that could now be applied to many fields. It was also a very slow revolution. Its roots are much older than the sixteenth century, mainly (i) the twelfth-century translations (chap. 10 above), (ii) the mediaeval universities (chap. 11), and (iii) the rise of the scholastic theologian/natural philosopher, as rightly pointed out by Grant. ${ }^{4}$ Some have argued that the preconditions for modern science lay in late mediaeval changes in society, especially economic ones: in a

1 See the useful encyclopaedia of Applebaum (2000). Shapin (1996) is an introduction to the topic. Wootton (2015), for instance, argues for the 'true' beginning of science only in this period.

2 In Koyré (1968: 89-113). Koyré admitted an exception in the study of the supra-lunar world in Antiquity, which did seek precision.

3 Lloyd (1987: 257), speaking of Hippocratic texts in Antiquity. He concludes (271) that 'no simple hypothesis to the effect that the ancients totally failed to make use of measurement will do'. He adduces counterexamples for geophysics, astronomy, harmonics, and optics.

4 Grant (1996: 171-176). 'These three pre-conditions just discussed [...] laid a foundation for the emergence of modern science because they provided an environment that was conducive to the study of science' (176). Grant also rightly stresses the importance of the Mediaeval Latin scientific vocabulary for the Scientific Revolution (198). 
more general tendency to measure things precisely and a greater monetarisation of society in the fourteenth century emerging, again, from scholastic philosophy. ${ }^{5}$ Some have stressed the Protestant view of science's utility to improve human life and society, although this goal is quite absent in many of the Scientific Revolution's main works and many were written by Catholics. ${ }^{6}$ It is striking that many of the important scientists of the revolution worked outside traditional universities, or at least were in contact with artisans and craftsmen who could devise new tools useful in many scientific branches. ${ }^{7}$ In other words, a rise of empiricism led to many of the new discoveries. This chapter reviews the discussion, now over half a century old, of whether a distinct epoch of revolutionary science from the midsixteenth century to the end of the seventeenth century is warranted (\$3) and then more specifically tries to shed light on what kind of language was used by these scientists (§5). Some data on the people and works involved in general (§2) and some prominent examples (§4) are also presented. Finally (§6), two of the most successful scientific authors of their time are compared (Kircher and Newton).

\$2 The important novelties that revolutionised many sciences are certainly quite far apart both in time and space, as the following list of some of the seminal works in the new spirit illustrates. This chronological list contains works up to and including Newton, and only those first published in Latin. The next chapter will list some more seminal works, now in the vernacular, mostly after Newton (chap. 14 $\S 3)$. In the course of roughly 150 years, many sciences changed fundamentally, but not all of them evolved in the same directions, as becomes especially evident from including non-natural sciences in the list. Most of these works are rightly famous and do not require a detailed description.

- Botany: Leonhart Fuchs, De historia stirpium (Basileae, 1542).

- Heliocentric astronomy: Nicolaus Copernicus, De revolutionibus orbium coelestium (Norimbergae, 1543), but influential only later, mainly through Johannes Kepler (1571-1630). ${ }^{8}$

5 Thus Kaye (1998).

6 Tambiah (1990: 12-13, based on Weber) sees this Scientific Revolution as a product of Puritan Anglicanism with its emphasis on utilitarianism, empiricism, and the improvement of nature, which - though an interesting observation of commonalities - goes much too far: many of the revolutionised sciences in the list below are not at all utilitarian or trying to improve nature, not even all of them are empirical, and few of the authors are Anglican. The new religious competition may, however, have helped to allow various kinds of novelty to gain ground.

7 This aspect is explored by Long (2011).

8 But see Gingerich $(2002,2004)$ for exceptions. 
- Anatomy using dissection: Andreas Vesalius, De humani corporis fabrica (Basileae, [1543]).

- Mining and geology: Georg Agricola, De natura fossilium (Basileae, 1546) and De re metallica (Basileae, 1566).

- Zoology: Conrad Gesner, Historia animalium, 5 vols (Tiguri, 1551-1587).

- Textual criticism: Francesco Robortello, De arte sive ratione corrigendi antiquorum libros disputatio (Patavii, 1557).

- Historical source criticism: Jean Bodin, Methodus ad facilem historiarum cognitionem (Parisii, 1566).

- Establishing change in the heavens (supernovae): Tycho Brahe, De nova et nullius aevi memoria prius visa stella (Hafniae, 1572).

- Symbolic mathematical notation: Franciscus Vieta, In artem analyticen isagoge (Turonis, 1591).

- Magnetism, electricity, and forces: William Gilbert, De magnete (Londini, 1600) and De mundo nostro sublunari philosophia nova (posthumous, Amstelodami, 1651).

- Chronography: Joseph Justus Scaliger, De emendatione temporum (Lutetiae, 1583) and Thesaurus temporum (Lugduni Batavorum, 1606).

- Mathematical astronomy: Johannes Kepler, Astronomia nova ([Heidelberg], 1609), and Galileo Galilei, Sidereus nuncius (Venetiis, 1610). ${ }^{9}$

- Empiricist methodology: Francis Bacon, Novum organon (Lugduni Batavorum, 1620).

- Blood circulation: William Harvey, Exercitatio anatomica de motu cordis et sanguinis in animalibus (Francofurti, 1628).

- Foundation of international law: Hugo Grotius, De iure belli ac pacis (Parisiis, 1625).

- Analytical geometry: René Descartes, Geometria (Lugduni Batavorum, 1649). ${ }^{10}$

- Sinology: Athanasius Kircher, China illustrata (Amstelodami, 1667).

- Stratification (geology): Nicolaus Steno, De solido intra solidum naturaliter contento (Florentiae, 1669).

- Ethics in mathematical form: Benedict Spinoza, Ethica ordine geometrico demonstrata ([Amsterdam], 1677).

- Scientific study of charters: Jean Mabillon, De re diplomatica, 2 vols (Luteciae Parisiorum, 1681-1704).

9 Galileo also published important works in the vernacular. Kepler complains about this as he could not read Italian (see Korenjak 2016: 237).

10 Descartes published this booklet in French in 1631 (as an appendix to his Discours de la méthode), but it became widely read only in the commented Latin translation by Frans van Schooten. 
- Differential calculus: Gottfried Wilhelm Leibniz, Nova methodus pro maximis et minimis, in Acta eruditorum (Lipsiae, 1684); also developed independently by Newton.

- Gravitation: Isaac Newton, Philosophiae naturalis principia mathematica (Londini, 1687).

We end the list (which has no pretensions to completeness) with Newton, whose first main work was published in Latin, his second (the 1704 Opticks) ${ }^{11}$ in English. Some of the listed authors also wrote in their vernacular languages, but Latin is still clearly the standard language, a situation that changes only in the eighteenth century. Geographically, it is striking that these works were first printed all over central and north-west Europe, but with a large proportion in Germanic countries, some also in France and Italy, largely corresponding to the former Carolingian Empire, apparently then still the centre of European innovation. ${ }^{12}$

If this period should be seen as the 'Scientific Revolution', it was one that not only encompassed the natural sciences (chap. 14 §3). As the list above shows, there were many groundbreaking publications in human and other sciences as well; a similar list for philosophy proper would also contain many groundbreaking works in the same timeframe. Thus, we might well suspect that the later sixteenth and the seventeenth centuries were in general favourable for new methodological approaches in many parts of intellectual life. Indeed, several of the quoted works use the adjective novus in their title, showing that there was a consciousness of wanting to do something new. ${ }^{13}$ Another uniting factor in the above works is that their results and methods go beyond and often even against Aristotle. Many lost faith in the Aristotelian causa finalis and tried to give mechanistic explanations of events. Nonetheless, the general approach to science was still very Aristotelian; the changes (such as stronger mathematisation) happened where new tools had become available that earlier Aristotelians lacked.

Again, translations from Greek - either new ones or now widely available ones through print - played a vital rôle for some of these new approaches (although less

11 But within two years, this was also published in Latin as Optice, sive de reflexionibus, refractionibus, inflexionibus et coloribus lucis libri tres (Londini, 1706).

12 The importance of Carolingian times for the later European Sonderweg is developed by Mitterauer (2004).

13 Many authors noted this. Campanella writes: saeculum nostrum plus historiae habet in annis centum, quam mundus totus in 4000 pluresque libri editi sunt in hoc centenario, quam in 5000 ('Our century has seen more history in a hundred years than the entire world in four thousand, and more books were published in this century than in five thousand'; Civitas solis, ed. Tornitore, p. 136). He then emphasises the importance of the printing press. 
strongly so than in the twelfth century). In 1482 Euclid's Elementa were printed in Latin; in 1544 Archimedes, Opera omnia (Greek and Latin, the translation from ca. 1450); in 1575 Diophantus, Arithmetica; in 1588 Pappus of Alexandria, Synagoge. But some of these works important for the 'New Science' had already been translated in the twelfth century without much effect (such as those by Archimedes). ${ }^{14}$ In the sixteenth century, all these works became very important for the further development of mathematics and subsequently of mathematical physics. Some of the new approaches are well exemplified by Galileo: a strong belief that mathematics is a better language for understanding nature than any other (a conviction that might be called Pythagorean-Platonist), its application in physics and astronomy (following Archimedes), but also the end of the learned disdain for technical apparatuses and manual work, ${ }^{15}$ and perhaps also a heightened awareness of the importance of scientific methodology (methodus also becomes an important word). However, mathematics is not the only kind of novelty that would make up even the revolution in the natural sciences.

\$3 Whether all these novelties together justify the term 'Scientific Revolution' is much debated, and although there is these days a tendency against it, ${ }^{16}$ there are some rather strong arguments in favour of it. ${ }^{17}$ It remains a fact that most sciences changed profoundly in these roughly 150 years, often more than in the entire time since their (mostly) Greek beginnings. The great amount of new things in society may have been the major trigger for change leading to a new inquisitive spirit and pride in novelty. On the other hand, new and old went hand-in-hand, and we must refrain from picking out ex post those authors (or works) that fit in best with what will later become the normal way of practising science (i.e. a combination of mathematics and empiricity) and term them the 'New Science'. Thus, Kepler the astronomer belongs to new science, Kepler the astrologist to the old, Newton the

14 But see Clagett (1978) on Archimedes' influence already in the Late Middle Ages.

15 See Rossi (1997: 126). Korenjak speaks of a 'Schulterschluss des Wissenschaftlich-Spekulativen und des Handwerklich-Praktischen, zweier Sphären, die man früher streng voneinander geschieden hatte' ('collaboration of the scientific-speculative and the artisanal-practical, two spheres that had previously been strictly separated'; 2016: 235).

16 Besides the arguments against discussed here, it would seem that the main driving force today against having a Scientific Revolution is the wish not to be 'Eurocentric' - an unscientific motive to be rejected.

17 Some of them are listed in Rossi (1997: xiv-xvii). For this question in general, see Teich (2015). Crombie (1952) covers the period between the end of Antiquity and the 'reflowering' (xi) of science, but rightly sees an essential continuity. Wootton (2015: 2) similarly explains 'why some think there was no such thing [as the Scientific Revolution], and why it is a sound category for historical analysis'. 
mathematical physicist must be contrasted with Newton the alchemist (§4), and so on. Besides, there were dead-end branches, such as Kircher’s (\$4) kind of universal science, that were much more influential in their day than many of the exponents of the 'Revolution'. Nevertheless, the new mathematico-empirical way of acquiring knowledge is certainly a striking novelty which produced astounding successes, although as emphasised in the motto by Mainzer above, this also had its precursors. The main 'heroes' of the Scientific Revolution belonged to very different schools of thought: from empiricists (Bacon), rationalists (Spinoza), deductivists (Descartes), and mechanicists (Newton), to adherents of the idea that mathematics is the true language of God (Galileo), they all competed during the 'Revolution'. ${ }^{18}$ The period of the fifteenth to the seventeenth century can be compared to the twelfth century in its groping in many new directions, some of them with lasting success, others not. Both the thirteenth and the later seventeenth and the eighteenth centuries then consolidated some of the new approaches of the previous century and developed their potential in greater depth. Thus, the eighteenth century appears with a single edifice of science, undoubtedly much larger than before, comprising many of the novel discoveries in early modern times. Of course, important epoch-making discoveries continue after the seventeenth century into our own time, and it is quite arbitrary to close the above list with Newton, but the main blueprint for what is to be considered as scientific and what not was to remain relatively fixed since then. Indeed, it was in the days of Newton that many authors became aware that science and thought had radically changed in the preceding century. It may well be Newton's impressive Principia (as late as 1684) that brought the breakthrough for this new combination of methods. In the later seventeenth century, a sense of a new scientific era is palpable in many authors, although there is certainly also the unsettledness of a changing world that subsides after the devastation of the Thirty Years War (1618-1648) and develops into what largely overlaps with the Baroque period.

As already pointed out in the previous chapter (chap. 12 \$1), what was definitely revolutionised in the second half of the fifteenth century was the horizon in which Europeans moved, their knowledge of the world outside Europe, ${ }^{19}$ their societies, and their means of communicating new ideas through the printing press. ${ }^{20}$ All of these processes together are used to define the beginning of modernity and the end of the Middle Ages: their influence on learning and science was

18 Some of these new approaches are explored by Dear (2009).

19 On science in and about the new territories, see Hsia (2001).

20 There are an estimated 28,500 incunabula titles known (Schmitz 2018: 357), printed in less than half a century. See Montecchi (2001) on the relation between early printing and science, especially the list of the first editions of scientific works from Antiquity (705). 
obviously very considerable too. Besides the Scientific Revolution, other movements such as antiquarianism appeared: ${ }^{21}$ the humanist interest in literary Roman Antiquity also sparked an interest in ancient Roman monuments, ruins, and works of art. Roman life as a whole was studied, a movement which would later grow into German Altertumswissenschaft. For instance, the discovery of the remarkably well-preserved remains of Pompeii in 1599 was a major event among intellectuals of the time.

\$4 During the Scientific Revolution, international communication among intellectuals was still done nearly exclusively in Latin; even in the case of authors who published important findings in Italian, French, or English first, Latin translations for the international market where soon to follow. ${ }^{22}$ Thus, the situation of intellectual bilingualism between mother tongue and the intellectual language Latin, which had already been in existence for more than a millennium, ${ }^{23}$ at first only shifted somewhat: discussions with fellow countrymen could now also be held in the vernacular, which had adapted to fulfil this rôle (see chap. 21 below), but international communication was still held in Latin. But what kind of Latin was used by the new scientists?

The topic of scientific Latin style in early modern times has hardly been addressed up to now. Some glimpses are presented in the next section, but more general and safer results about such scientists' Latin can be expected from Korenjak's Noscemus project (Nova Scientia: Early Modern Scientific Literature and Latin), which runs from 2017 to $2022 .{ }^{24}$ In this section, some specimens of Latin from some writers of the Scientific Revolution are presented. ${ }^{25}$ Just as their methods differed significantly, so too did their Latin. Some of the roots of the new approaches in natural science have already been discussed: experimentally minded natural magic (chap. 12) and a Pythagorean view of the (near-)divinity of numbers, well exemplified by Copernicus, Kepler, and Galileo.

Nicolaus Copernicus (1473-1543) was a Renaissance polymath: he studied law, learned Greek, and then studied medicine. But it was mathematics and its

21 Initiated by Flavio Biondo, Roma triumphans ([Brescia], ca. 1473; INKA 4424).

22 See Grant (1954); Burke (2007).

23 See Haye (2005).

24 https://wiki.uibk.ac.at/noscemus/Main_Page . It will cover only the natural sciences, and one of its results will be a representative database of some 1,500 works and a digital sourcebook with some 200 digital full texts. There will also be monographs by Korenjak and his collaborators.

25 Portraits of eleven of the most important natural scientists of this time can be found in Petruccioli (2001-2004: 5:part 3). Olschki (1919-1927: 2:65-111) reviewed the Latin style of some important authors. 
application to the movement of the heavenly bodies that made him famous. ${ }^{26} \mathrm{His}$ famous major work, De revolutionibus orbium coelestium, was finished on his deathbed (Norimbergae, 1543). Much of it consists of very theoretical mathematical calculations and lists of observational data, but in some parts (especially book I) the author shows his enthusiasm for Renaissance Platonism and his love of the Greek classics by positing the Sun, the visibilis deus as he calls it, at the centre of the universe (De revolutionibus orbium coelestium I.10, ed. Lerner, Segonds \& Verdet, vol. 2, p. 38):

Quis enim in hoc pulcherrimo templo lampadem hanc in alio meliori loco poneret, quam unde totum simul possit illuminare? Siquidem non inepte quidam 'lucernam mundi', alii 'mentem', alii 'rectorem' vocant. Trismegistus 'visibilem Deum', Sophoclis Electra 'intuentem omnia'. Ita profecto tanquam in solio regali Sol residens circumagentem gubernat Astrorum familiam.

'Who would position that light [the Sun] in this most beautiful temple [the world] at a better spot than the one from which it can illumine the entire world at once? If indeed some call Him not unfittingly "lamp of the world", others "mind", others "ruler", Trismegistus "visible god", Sophocles' Electra "the all-seer”, so, assuredly, the Sun rules the entire family of revolving heavenly bodies as if seated in a kingly throne. ${ }^{27}$

Perhaps as an expression of caution in times of religious upheaval, his printer Osiander added an alleviating preface claiming that the entire book was only a theoretical exercise. In his introduction [a]d lectorem, de hypothesibus huius operis (Norimbergae, 1543 edition, before pagination), ${ }^{28}$ he states among other things:

Neque enim necesse est, eas hypotheses esse veras, imò ne verisimiles quidem, sed sufficit hoc unum, si calculum observationibus congruentem exhibeant.

'It is not necessary that these hypotheses be true, not even probable; this one thing suffices: if the calculations are in agreement with observation.'

The book's success was at first rather limited. As Goddu (2010: 406-409) points out, the reasons for this were more of a scientific than of a religious nature. Only with Galileo's and Kepler's (1571-1630) further work (leading to the discovery of the famous Kepler laws) was the theory in itself made plausible. Kepler too was deeply immersed in Renaissance neo-Platonism. Incidentally, Kepler provides a

26 For an introduction to his life and thought, see Goddu (2010). The amount of literature about Copernicus and the other major heroes of the Scientific Revolution is enormous.

27 A similar Sun theology is further elaborated into a veritable Sun-religion, where God resides in the Sun and the souls of the dead in the stars, by Tommaso Campanella, Civitas solis, nearly a century later.

28 https://www.e-rara.ch/zut/content/pageview/124056. 
list of what he considered sciences that fits in very well with the broad 'German' approach we met above (see chap. 1; Somnium, nota 35, ed. Frisch, p. 43):

1. metaphysica, 2. physica, 3. ethica, 4. astronomia, 5. astrologia, 6. optica, 7. musica, 8. geometria, 9. arithmetica.

The divine nature of geometric entities is pointed out emphatically by Galileo Galilei (1564-1642), who often wrote in Italian. ${ }^{29}$ He states (Il saggiatore 6, ed. Besomi et al., p. 119): ${ }^{30}$

La filosofia è scritta in questo grandissimo libro, che continuamente ci sta aperto innanzi agli occhi (io dico l'Universo), ma non si può intendere, se prima non s'impara a intender la lingua, e conoscer i caratteri ne' quali è scritto. Egli è scritto in lingua matematica, e i caratteri son triangoli, cerchi ed altre figure geometriche, senza i quali mezzi è impossibile intenderne umanamente parola; senza questi è un aggirarsi vanamente per un oscuro laberinto. 'Philosophy is written in this great book, which lies constantly open before our eyes (I mean the Universe), but you cannot understand it unless you first learn to understand its language and to know the characters with which it is written. It is written in mathematical language, and the characters are triangles, circles, and other geometric figures, without which means it is impossible for humanity to understand it; without them, there is a vain wandering through a dark labyrinth.'

Thus, for Galileo God's language is mathematics - not, as it used to be believed in the Middle Ages, Hebrew or any other human language. He also expounded this in detail in his Systema cosmicum, ${ }^{31}$ his famous discussion of whether geocentricism or heliocentricism was to be preferred. At the end of the first day of the discussion, Salviati (who speaks for Galileo against the fictitious Aristotelian Simplicius) argues as follows (Londini, 1663 edition, p. 137):

Ut ergo me rectius explicem, aio, quod ad veritatem, cuius cognitio mathematicis demonstrationibus paratur, eandem illam esse cum ea quam divina sapientia cognoscit. Id vero tibi facile largiar, modum illum, quo Deus cognoscit infinitas propositiones, quarum nos paucas aliquas cognoscimus, summe excellentiorem esse nostro modo, qui ratiocinando de conclusione progreditur in conclusionem, cum Dei modus simplici absolvatur intuitu.

29 On his Latin, see Berno (2006/2007).

30 This work is a prime example of how certain modern circles write one-sided hagiography of their scientific heroes. In it Galileo wrongly and with much bile argues against the Jesuit Orazio Grassi that comets are sublunar phenomena. This and other failures of Galileo are often swept under the rug.

31 This is the Latin translation of Galileo's Dialogo dei due massimi sistemi by his friend Matthias Bernegger. Italian was clearly not acceptable for an international reception; Kepler, for instance, did not read Italian. For the Italian text, cf. Galileo, Opere, ed. Flora, p. 110. On this work, see https://wiki.uibk.ac.at/noscemus/Systema_cosmicum. 
'In order that I explain myself better, I say that concerning truth, whose knowledge is provided by mathematical proofs, it is the same as the one that divine Wisdom [i.e. God] knows. I grant you freely that the manner in which God knows infinite propositions, of which we know but few, is by far better than ours, which has to proceed by reasoning from one conclusion to the next, while God's manner is resolved by mere looking.'

Whereas Galileo stands for the mathematical approach, a new inquisitive and empirical spirit and a pessimistic outlook on what is already known is shown by the English Lord Chancellor Francis Bacon (1561-1626) in his Novum organon (praef., ed. Krohn, p. 12) from 1620:

De statu scientiarum, quod non sit foelix aut majorem in modum auctus; quodque alia omnino quam prioribus cognita fuerit via aperienda sit intellectui humano, et alia comparanda auxilia, ut mens suo jure in rerum naturam uti possit.

Videntur nobis homines nec opes nec vires suas bene nosse; verum de illis majora quam par est, de his minora credere. Ita fit, ut aut artes receptas insanis pretiis aestimantes nil amplius quaerant, aut seipsos plus aequo contemnentes vires suas in levioribus consumant, in iis quae ad summum rei faciant non experiantur. Quare sunt et suae scientiis columnae tanquam fatales; cum ad ulterius penetrandum homines nec desiderio nec spe excitentur.

'That the status of the sciences is not prosperous, nor advancing in a great way, and that a completely different path has to be trodden by the human intellect than the one known to our predecessors, and other helps provided in order that the mind be able to use its proper laws toward the nature of things.

It seems to me that men do not know either their property or their possibilities well: they think too highly of the former and too low of the latter. Hence it happens that either they esteem the received arts insanely highly and seek no further, or else that they belittle themselves more than is just and expend their strength on minor matters and do not exercise their powers in things that strive for the highest. This is like the pillars of fate for science, because men are encouraged to penetrate more deeply neither by desire nor by hope.'

Bacon is often hailed as the father of the empirical method. Although he was not active as a scientist himself, his methodological considerations were indeed influential. His scepticism is related to a disdain for scholastic 'sophistry'. Much of his (unfinished) work consists of aphorisms, such as the following (no. 14, ed. Krohn, p. 86):

Syllogismus ex propositionibus constat, propositiones ex verbis, verba notionum tesserae sunt. Itaque si notiones ipsae (id quod basis rei est) confusae sint, et temere a rebus abstractae; nihil in iis, quae superstruuntur, est firmitudinis. Itaque spes est una in inductione vera.

'A syllogism consists of propositions, propositions of words, and words are the tokens of notions. Thus, if the notions themselves (which are the basis of the matter) are confused, and rashly abstracted from things, nothing of what is built upon them is firm. Thus, our only hope is true induction.' 
René Descartes (1596-1650, in Latin 'Cartesius') was one of the early adopters of French in scholarly writing. Most of his correspondence ${ }^{32}$ and many of his treatises are written in French (Opera, ed. Adam et al.). Many works were translated into Latin before long, either by himself or by others. Descartes is today mostly remembered as a philosopher, but he also proposed a new mechanical worldview based on vortices of matter, and made important contributions to mathematics and physics. In fact, the philosopher and the scientist have often been considered separately. ${ }^{33}$ Like Lullus, he envisaged a universal science, mathesis universalis. His Principia philosophiae (1644) was first published in Latin. It shows well that for Descartes, philosophy and natural science go hand-in-hand. Much of the text is concerned with his vortex theory and with the mechanics of the solar system. An excerpt from it, here a passage about sunspots, will serve to illustrate his language. The geometric relations are illustrated with a graphic (fig. 22; Principia philosophiae, Amstelodami, 1692 edition, p. 104):

Quomodo materia primi elementi per istos meatus fluat.

Ita igitur materia primi elementi utrimque ex polis per istos meatus ad sidus I potest peruenire; ac quia eius particulae striatae caeteris sunt crassiores, ideoque maiorem habent uim ad pergendum secundum lineas rectas, non solent in eo manere, sed ingressae per $f$, protinus egrediuntur per d, atque ibi occurrentes globulis secundi elementi, uel materiae primi a B uenienti, non possunt ulterius pergere secundum lineas rectas, sed, in omnes partes reflexae, per aetherem circumfusum $x x$ uersus hemisphaerium efg reuertuntur; et quotquot ingredi possunt meatus maculae, uel macularum, quae ibi sidus istud tegunt, per illos rursus progrediuntur ab $f a d d$; sicque assidue per medium sidus transeundo, et per aetherem circumfusum redeundo, quendam ibi quasi uorticem componunt.

'How matter of the first element flows in such trajectories.

Thus matter of the first element can reach the star (I) from both sides in such trajectories, and because its furrowed particles are denser that others, they have more force to move in straight lines, they do not stay in it [the star], but if they have entered at $f$, they will directly exit at $d$, and there meeting particles of the second element or matter of the first coming from $\mathrm{B}$, they can no longer move in a straight line, but they are reflected everywhere by the surrounding aether $(\mathrm{x})$, they return toward the hemisphere efg. And as many trajectories of a spot or spots, which can cover the star there, can enter, they exit again from $\mathrm{f}$ to $\mathrm{d}$. Thus, they pass constantly through the middle of the star and return from the surrounding aether, which they form like a vortex [around the star].'

32 An exception is that with his opponent Gisbertus Voetius.

33 Rodis-Lewis (1987) is a collection of essays on his approaches in the natural sciences. For an introduction to Descartes the scientist, see Armogathe (2002). 


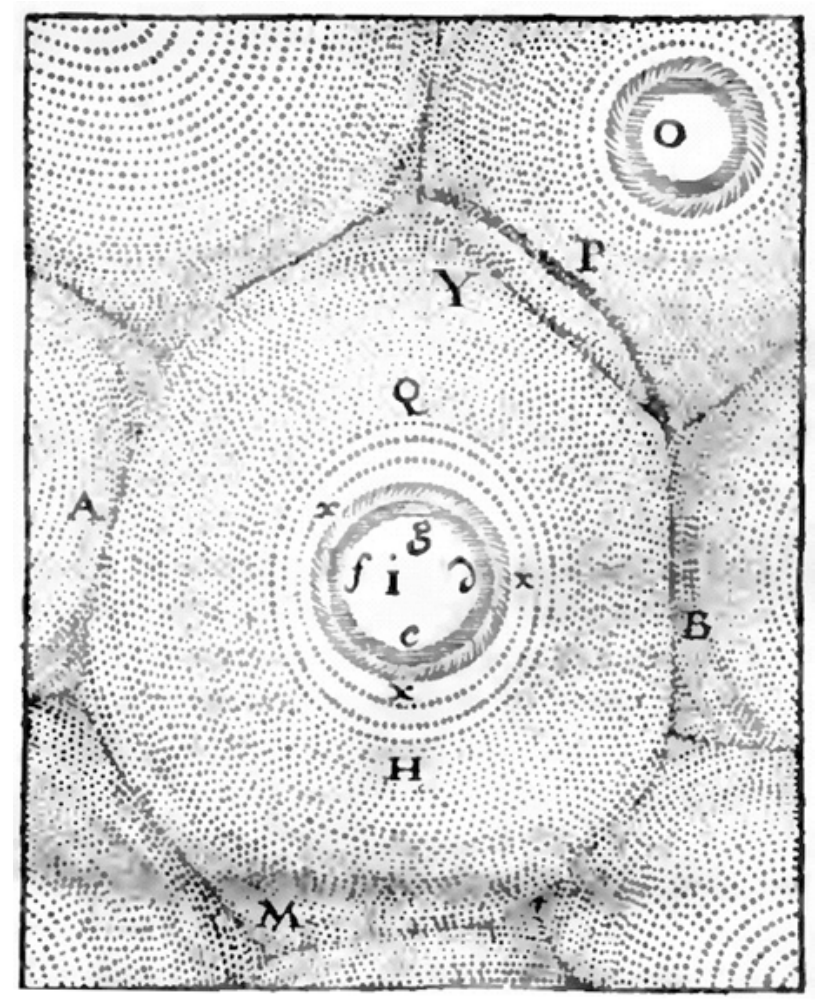

Fig. 22: The Sun (centre) in stellar vortices.

Descartes's contemporary Athanasius Kircher (1602-1680) was a German Jesuit who became the Habsburg court mathematician (as Kepler had been) but finally ended up in Rome at the Jesuit headquarters, the Collegium Romanum, where he taught mathematics, physics, and oriental languages. ${ }^{34}$ The Collegium Romanum was actually very similar to the kind of scientific institution free from state control that Francis Bacon had envisioned a few decades previously (1627, in New Atlantis): ${ }^{35}$ all information from the near-worldwide Jesuit missions converged there, furnishing the inquisitive Kircher with scientifically interesting data and objects. His collection of curiosa grew into one of the earliest museums, the museo kircheriano. ${ }^{36}$ As an example of Kircher's way of practising science, we will consider his

34 On the Jesuits' relation to science, see Feingold (2003b).

35 Although, of course, Bacon would not have approved of Church control either.

36 Its exhibits are now spread among several Roman museums. See Findlen (2003). 
China illustrata, which was the most scientific general treatment of Chinese culture then in existence and was to be very influential in Europe's perception of China. ${ }^{37}$ Some background is required: Kircher's work stands at the beginning of scientific sinology in Europe. Indeed, European sinology may be said to begin with the discovery of the famous 'Nestorian Stele' in Xi'an (1623 or 1625), which proved Christian presence in China since the seventh century. Kircher had first made its text known in Europe in his Prodromus coptus (pp. 54-69, 74-85). ${ }^{38}$ In his 'summa', China illustrata, thirty years later, Kircher reproduced the rather faulty initial translation of the stele's text, but this time he added a word-for-word translation from the Chinese that is better. In general, the text was clearly hastily penned and is surprisingly sloppy. ${ }^{39}$ Kircher's main scientific contribution of his own lay in the reading of the Syriac parts of the stele's inscription; for the Chinese, he relied on Jesuit collaborators. Indeed, China illustrata is based on the contributions of many Jesuit missionaries working in the regions described and is clearly a community work. Besides the stele, it also treats Chinese geography in a scientific way: Kircher uses the geographic coordinates of mentioned places when known to him, and admits doubt in unclear matters. On the other hand, he fails to be consistent in simple things such as the spelling of names. ${ }^{40}$ Curiosa are still an important part of the work, but they are treated in a relatively scientific spirit, more like Seneca did than, say, Solinus. Kircher includes a comprehensive bibliography of other Jesuits (pp. 117-121). Part III, chapter 1 (pp. 129-151) presents a comparative study of idols, reaching the (wrong) conclusion that Chinese idolatry can be traced back to Egyptian idolatry. A sample (p. 131; see Wengchao Li 2020: 86-87):

TRes igitur Sinarum Libri Orbis terrarum sectas numerant; sic enim vocant Regnum suum una cum vicinis adiacentibus locis, alias enim minime norunt.

Prima est Literatorum; altera Sciequia; tertiam Lançu vocant. Ex his tribus aliquam Sinæ omnes \& reliqui populi contermini, qui Sinarum characteres habent, profitentur; quales sunt Iapones, Coriani, Tonchini \& Cocincinenses populi, de quibus postea dicemus.

'The books of the Chinese world thus count three religions, for this is what they call their own kingdom together with the adjacent places; they do not know others.

37 There is now a commentary on the work in Wengchao $\mathrm{Li}$ (2020).

38 The European literature about this stele from its discovery to today is astonishingly large. The state-of-the-art edition and discussion is Pelliot (1996: 108-110, 116-118 on Kircher's two translations).

39 For instance, on p. 29 a wrongly printed parenthesis makes it unclear what is Kircher's (pertinent) comment, and what stands on the stele: [...] (alludit ad hoc secta Pagodum \& Literatorum) [erroneous parenthesis] [...] comprehendi queat [correct position for the parenthesis].

40 Cingiscan is followed by cham; for the un-Latin sound $/ \mathrm{J} /$, sch is used if the source was a German missionary, sci if an Italian, even for one and the same Chinese name, producing unnecessary obscurity. 
The first is the one of the literati [Confucians], the second of the śākyamuni [Buddha], the third is called Laozi [Taoism]. ${ }^{41}$ All Chinese and the other adjacent peoples who use Chinese characters confess one of these three. These are the Japanese, Koreans, northern Vietnamese, and southern Vietnamese peoples, about which we will speak later.'

His language in this work is, as is typical for him, full of quotations in many languages and alphabets; his Latin in the preface is syntactically very complicated, although it rather fails to reach Ciceronian elegance. In the rest of the work, it is plainer. Unlike in many other scientific texts (see chap. 18 §3), the ablativus absolutus is a common feature, sometimes even one within another one (p. 88):

Novo itaque Pontifice, sub nomine Gregorii X. Rudolpho imperante, unanimibus Cardinalium suffragiis electo, Anconam revertuntur.

'As then a new Pope with the name Gregory X had been elected unanimously by the votes of the cardinals, during the reign of Emperor Rudolph [I of Germany], they returned to Ancona.'

Benedictus Spinoza (1632-1677), born into a Jewish family (although later expelled from the community), received both a Hebrew and a Latin education. He earned his livelihood as a lens-maker. His importance lies mostly in the human sciences and philosophy: political thought, biblical studies, ethics. Euclid's axiomatic method inspired him to try similar approaches in the human sciences, especially in his Ethica ordine geometrico demonstrata ([Amsterdam], 1677). In biblical studies he demonstrated that the five books of Moses cannot have been written by Moses (which did not win him friends). His philosophy emphasising the immanence of God and the importance of human freedom was also very controversial but much read, especially among German philosophers. There was no lasting success for his axiomatic approach in the human sciences. His language and approach can be illustrated by this typical excerpt (Ethica ordine geometrico demonstrata IV.71, ed. Bartuschat, p. 500):

Soli homines liberi erga invicem gratissimi sunt.

DEMONSTRATIO. Soli homines liberi sibi invicem utilissimi sunt et maxima amicitiae necessitudine invicem iunguntur (per prop. 35. huius et eius coroll. 1.), parique amoris studio sibi invicem benefacere conantur (per prop. 37. huius). Adeoque (per aff. defin. 34.) soli homines liberi erga se invicem gratissimi sunt. Q.E.D.

41 The point made above about the spelling is nicely illustrated here: Sciequia will have come from an Italian missionary, Lançu from a Portuguese one whose pronunciation of Laozi may have been wrongly taken by another Romance-speaker as nasalising an $n$ (compare e.g. Portuguese cão for canis). 
'Only free men are truly grateful to one another.

Proof. Only free men are of greatest use to one another and are joined by greatest necessity of friendship (as from theorem 35 of this book and its first corollary), and they try with equal fervour to do good to one another (as from theorem 37 of this book). And thus (through definition 34 on affects) only free men are truly grateful to one another. Q.E.D.'

Similar methods were used by Isaac Newton (1643-1727) with greater success. He may have been the man to unite the two new positions of empiricism and mathematisation firmly and lastingly. His strictly mathematical theory of gravitation, meant to hold equally in all parts of the universe, revolutionised physics. Newton is also famous for his strong criticism of scientists who forged hypotheses on uncertain grounds (intending especially Descartes); nonetheless, he himself believed, for instance, in absolute space and time because of his views of God constituting them. ${ }^{42}$ Newton, Principia mathematica, Praefatio ad lectorem ${ }^{43}$ states:

Cum veteres mechanicam (uti auctor est Pappus) in rerum naturalium investigatione maximi fecerint, et recentiores, missis formis substantialibus et qualitatibus occultis, phaenomena naturae ad leges mathematicas revocare aggressi sint: visum est in hoc tractatu mathesin excolere quatenus ea ad philosophiam spectat.

'As the ancients (as Pappus testifies) made great account of mechanics ${ }^{44}$ in the investigation of natural things, and more recent scientists, after dismissing substantial forms and occult qualities, have undertaken to reduce the phenomena of nature to mathematical laws, it will be seen that mathematics is applied in this treatise as far as it regards natural philosophy.'

Later in the book, Newton's language soon becomes very mathematical and formal, as the following example concerning circular motion in viscous media illustrates (Principia mathematica II.4, lem. III, commented edition, p. 536): ${ }^{45}$

42 Already mentioned above (chap. 4 §3). Burtt (1954); Wagner (1969); Wagner (2011); Harper (2011). In Principia mathematica I, def. VIII, scholium (1687 edition, p. 5), Newton defines tempus absolutum and spatium absolutum; besides, he claims that [s]patium absolutum natura sua absque relatione ad externum quodvis semper manet similare et immobile ('absolute space always remains similar and immobile by its own nature without reference to anything external') - all of which are metaphysical hypotheses, and are, in fact, no longer shared among physicists today. 43 Before pagination; p. $\mathrm{x}$ in the commented edition of 1833. See on this work https://wiki.uibk. ac.at/noscemus/Philosophiae_naturalis_principia_mathematica.

44 On the next page, Newton defines mechanics as rationalis Scientia Motuum qui ex viribus quibuscunque resultant, \& virium quæ ad motus quoscunque requiruntur ('the rational science of movements which result from any forces and of the forces required for any movements').

45 This lemma discusses a property of the logarithmic spiral, in polar coordinates $r=a e^{b \theta}$. Jacob Bernoulli (1655-1705) called it the spira mirabilis and wanted it inscribed on his gravestone with the motto eadem mutata resurgo ('although changed, I arise as the same'). 


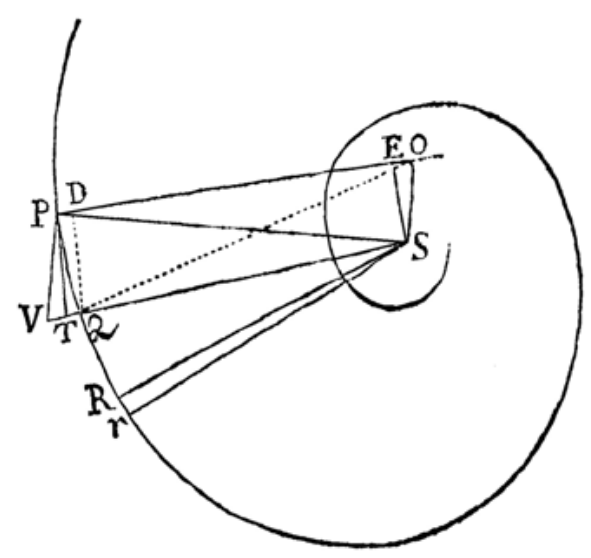

Sit PQRr Spiralis quæ secet radios omnes SP, SQ, SR, \&c. in æqualibus angulis. Agatur recta PT $q u æ$ tangat eandem in puncto quovis $P$, secetque radium $S Q$ in $T$; \& ad Spiralem erectis perpendiculis $P O, Q O$ concurrentibus in $O$, jungatur SO. Dico quod si puncta $P \& Q$ accedant ad invicem \& coeant, angulus PSO evadet rectus, \& ultima ratio rectanguli $T Q \times 2 P S$ ad $P Q$ quad. erit ratio æqualitatis.

Etenim de angulis rectis $O P Q, O Q R$ subducantur anguli æquales $S P Q, S Q R$, \& manebunt anguli æquales OPS, OQS. Ergo circulus qui transit per puncta $O, S, P$ transibit etiam per punctum $Q$. Coeant puncta $P \& Q, \&$ hic circulus in loco coitus $P Q$ tanget Spiralem, adeoque perpendiculariter secabit rectam OP. Fiet igitur OP diameter circuli hujus, \& angulus OSP in semicirculo rectus. Q.E.D.

'Let PQRr be a spiral which cuts all the radii SP, SQ, SR, etc. in equal angles [i.e. a logarithmic spiral]. The straight line PT be drawn, which touches the spiral in a point $P$, and cuts the [prolonged] radius SQ in T. Perpendicular lines to the spiral PO and QO being drawn, meeting in $\mathrm{O}$, this point be joined to form SO. I claim that if the points $\mathrm{P}$ and $\mathrm{Q}$ approach one another and [finally] coincide, the angle PSO will become a right angle, and the final ratio of the rectangle $\mathrm{TQ} \cdot 2 \mathrm{PS}$ to $\mathrm{PQ}^{2}$ will become the ratio of equality [i.e. $\mathrm{TQ} \cdot 2 \mathrm{PS}=\mathrm{PQ}^{2}$ ].

[Proof] Indeed from the right angles $\mathrm{OPQ}, \mathrm{OQR}$ let there be subtracted the equal angles SPQ, SQR and there will remain equal angles OPS, OQS. Therefore a circle which passes through points $\mathrm{O}, \mathrm{S}, \mathrm{P}$ will also pass through point $\mathrm{Q}$. Let the points $\mathrm{P}$ and $\mathrm{Q}$ coincide and this circle will touch the spiral in the place of coincidence $\mathrm{PQ}$ and will therefore cut the right line OP perpendicularly. OP will become a diameter of this circle, and the angle OSP will become a right one as it stands in a semicircle. Q.E.D. ${ }^{46}$

Like Euclid, Newton often used letter symbols to denote mathematical objects, and the many graphics included are often necessary to understand the geometric facts. ${ }^{47}$ It has been claimed that English nominal scientific style owns much to

46 We omit the second part of the proof.

47 For Euclid see chap. $22 \S 4$ below. 
Newton's Latinising English. ${ }^{48}$ The work is very formalised, consisting of lemmata, theorems, formulae, and the like. The language is very nominal, participles and ablative absolutes are used to formulate conditions, finite verbs are often just the copula or impersonal passives, like in modern English science books, and besides (due to the topic) the verb movere is common. It would seem that not only Newton's methods became paradigmatic for the New Science but also his language. His book reads like a modern mathematics or physics book. But Newton's approach is still much more geometric than that used by physicists today; only rarely does he use equations ('=' appears 87 times), and much more often he uses ratios to express what would now be expressed by an equation. ${ }^{49}$

Newton's strong interest in theology and the Old Testament could not lead to publications because his heretical anti-Trinitarian views were punishable by death in England. His third main interest was alchemy. ${ }^{50}$ The question of the relation between his physical and his alchemical studies has often been discussed, Dobbs (1975: 210-213) sees the latter as important for the conception of 'force' in the former, among other things. At any rate, it should not be concluded overhastily from the fact that Newton did not publish his alchemical works that they mattered little to him. Dobbs (194-196) makes it more plausible that he believed their content to be too dangerous to be publicly accessible. The language in his alchemical notes stands in stark contrast to that of the Principia. Here is an arbitrary example quotation from his alchemical manuscripts: ${ }^{51}$

Totum opus in unicâ re consistit. Educ salem e metallis: qui est unicus clavis nam omnis generatio fit ex spermate. Metalla ignem non passa debent sumi. Arca arcanorum.

'The entire work consists in only one thing: lead salt out of metals, which alone [the salt] is the key, for all generation comes from seed. Metals that have not suffered fire must be used. Chest of secrets.'

Chemistry had to wait another half-century to undergo a process of formalisation of the kind that Newton performed for gravitation theory. Apparently, he failed to see the use of his own approach in the field of the transmutation of chemical substances. Both his alchemical and theological works would have fared much worse

48 See Banks (2008: 59-63), who studies nominalised processes in an excerpt from the Principia and quotes further literature.

49 The equals sign '=' only gained wide acceptance in the early eighteenth century; see Cajori (1928-1930: 1:305).

50 Dobbs (1975) studies this facet of Newton in depth. His manuscripts are online at http:// webapp1.dlib.indiana.edu/newton/.

51 Cambridge University, King's College Library, Keynes MS. 12, fol. 1r, online at http://webapp1. dlib.indiana.edu/newton/mss/norm/ALCHO0001/ 
than his physical ones had they not been completely ignored by posterity. We shall return to Newton's seemingly contradictory scientific approaches below (\$6).

Gottfried Wilhelm Leibniz (1646-1716) read, spoke, and wrote many languages, but his main works are written in Latin, French, and German. Besides his important contributions to mathematics, physics, and philosophy, his interest in languages and linguistics is evident; he even considers active Latin language engineering by, for instance, introducing what he calls tempora nominum ${ }^{52}$ such as amavitio and amaturitio for past and future 'loving' respectively. In this, like in his combinatorics, he seems to have been influenced by Lullus (see chap. 12 §5). Leibniz is clearly interested in Latin only as a vehicle for scientific content, not in style and beauty. Indeed, his language looks quite scholastic, as this example shows (De vero et falso 9, Akademieausgabe, ser. 6, vol. 4, p. 738):

Affirmatio et negatio negationis aequipollent. Est axioma fluens ex ipso significatu $\tau$ toṽ non, seu particulae negativae, cujus hic est usus, ut geminatione semet ipsam tollat.

'Affirmation and the negation of negation are equivalent. This is an axiom following directly from the meaning of "not", that is, the particle of negation which is used here, which by being doubled cancels itself out.'

Besides the conspicuous Greek article used here, ${ }^{53}$ Leibniz often uses other Greek terms in his writings that were apparently felt to be hard to express in Latin,

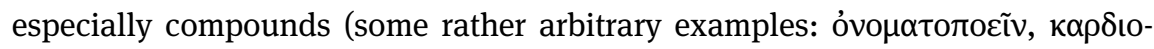

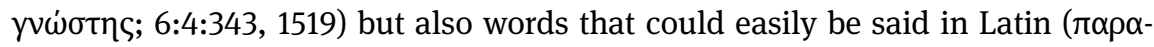

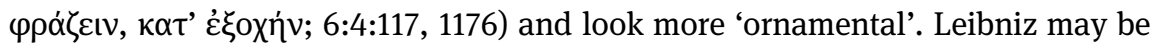
said to be a typical exponent of academic Latin (see chap. 18 §9). Especially in his contributions to the human sciences, quotations in countless languages and alphabets, formulas, and diagrams similar to those in Kircher are to be found.

To conclude this overview, three texts outside the usual timespan of the Scientific Revolution are considered, two early and one late. Leonhart Fuchs's De historia stirpium (1542) ${ }^{54}$ reached a new level of accuracy in botanical description, helped by engravings and thus by the then still relatively young technique of book-printing. The author has to justify the illustrations (p. [17]) against contemptores pictur$a e$. The work proper is preceded by a very humanist dedicatory letter quoting huge numbers of antique Greek and Latin authorities. Here is an example from the chapter De cannabe (Basileae, 1542 edition, p. 392):

52 In Leibniz, Opuscules, p. 289.

53 On this surrogate article, see chap. $24 \S 2$.

54 See https://wiki.uibk.ac.at/noscemus/De_historia_stirpium. 


\begin{abstract}
KANNABIS Graecis, Cannabis Latinis, Barbaris \& uulgo Canapus dicitur, Germanis autem

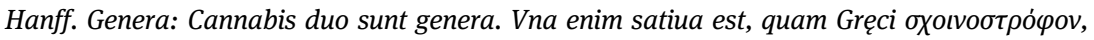
quod magni in uita usus sit ad robustissimos funes texendos. Germanis zamer Hanff dicitur. Altera syluestris, quam Latini Terminalem uocant, Germani wilden Hanff. Forma: Satiua Cannabis folia fert fraxino similia, grauis odoris, caules longos, inanesque, semen rotundum. Syluestris uerò uirgas fundit Altheae similes, nigriores, asperiores \& minores, cubitali altitudine. Folia satiuae similia, asperiora \& nigriora. Flores subrubeos, Lychnidi similes. Semen \& radicem Altheæ similia. Eius effigiem uidere nondum licuit. Locus: Satiua, in locis cultis sata prouenit. Sylvestris in sylvis \& asperis locis, Apuleioque teste, iuxta semitas \& sepes nascitur. Tempus: Herba ad usus medicos carpitur dum maxime uiret. Semen autem eius, Plinio auctore, cum maturum est, id quod prope autumni aequinoctium accidit. Temperamentum: Admodum calefacit \& exiccat. ${ }^{55}$

'In Greek kóvvaßıৎ, in Latin cannabis, among uncultured people and vulgarly called cannapus, in German Hanf. Kinds: there are two kinds of hemp. One is cultivated, called

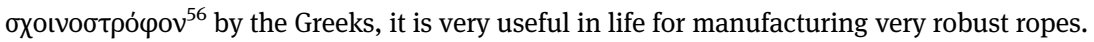
In German zahmer Hanf [tame hemp]. The other is wild, the Latins call it terminalis, the Germans wilder Hanf [wild hemp]. Form: cultivated hemp has leaves similar to ashes, a strong smell, long and hollow stalks, round seeds. The wild one spreads twigs similar to mallow but blacker, rougher, smaller, one cubit in height. The leaves are similar to the cultivated kind. The flowers reddish, similar to campion. Seeds and the root similar to mallows. I have not yet managed to see it. Place: the cultivated kind appears when sown, the wild one in forests and rough places. According to Apuleius, it grows close to paths and fences. Time: The herb is collected for medicinal purposes when it is most green, but its seed, according to Pliny, when it is mature, which occurs close to the autumnal equinox. Temperament: it strongly heats and dries out.'
\end{abstract}

This same style of description is used for all the approximately five hundred plants covered. The medicinal background and the language would still seem rather mediaeval, but the quality of the descriptions and the approach of comparing plants look modern and were groundbreaking for botany. The book is purely descriptive in method, but its way of describing plants has remained in use ever since (more details in chap. $15 \S 5$ below). Fuchs's major antique predecessor was Dioscurides (ca. 40-90); a late antique illustrated copy of his work De materia medica has survived. ${ }^{57}$ The importance of descriptive science is sometimes underestimated: ${ }^{58}$ gathering reliable data is a very important step in science. Often, great theoretical advances could only be made after much accurate description had been gathered. In the case of botany, a further crucial step will be Linnaeus' nomenclature (chap. 15 §5). Today, of course, botany has long ceased to be a

55 A list of uses from antique authors follows.

56 Literally 'rope-maker'. The term is mentioned in Dioscurides.

57 Ed. Mazal, also with facsimile and commentary. See fig. 28 below for an example.

58 On the 'science of describing', see Ogilvie (2006). 
'merely' descriptive science. The following work was also of crucial significance; its advances are both in description and in theory.

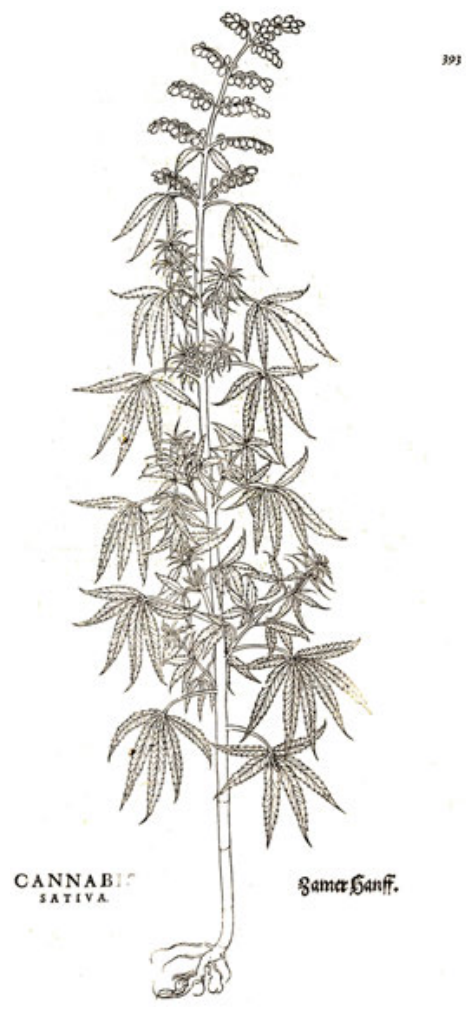

Fig. 23: Illustration of the male hemp plant from Fuchs (1542 edition, p. 393).

Andreas Vesalius' De humani corporis fabrica ${ }^{59}$ was groundbreaking for human anatomy: again, its precision and its very high quality illustrations, which are rightly famous, make it stand out (an example is printed in figure 24; it does not belong to the quoted text). A random excerpt will give an impression of his unusual Latin (De humani corporis fabrica I.60, De ossium numero):

Parum dubito plerosque alicubi a me ossium quoque numerum desideraturos: quibus nullum aliud consilium dari uelim, quam, ut ex singulis huius libri Capitibus illum petant. prolixius enim esset, hic omnia recensere. Quamuis ne tantillum laboris subterfugisse uidear, non enu-

59 See https://wiki.uibk.ac.at/noscemus/De_humani_corporis_fabrica. 
meratis appendicibus, et ossibus ita ut in prouectioris ætatis hominibus se habent, constitutis, ad hunc modum ea recensere nihil impediet.

'There is little doubt that there will be many wishing to hear from me the number of all the bones. I would give them no other advice than to seek it out from the individual chapters of this book, for it would be too lengthy to muster them all again. However, in order not to seem to have fled such a trifle of work, without counting appendices and considering the bones as they are in adult age, nothing impedes counting them in the following way.'

Vesalius' Latin is definitely classicist, with complicated formulations and sometimes rare words (such as tantillum in this passage). The above paragraph, which is quite typical, could be reduced to one short sentence without losing any scientific information. We will see that this kind of humanist Latin in the sciences is an exception.

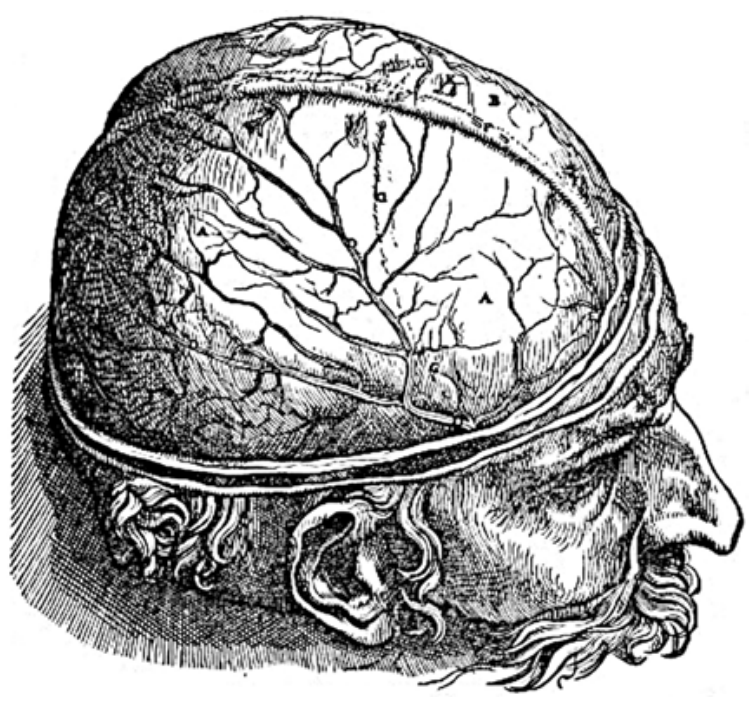

Fig. 24: Blood vessels in the scalp, from Vesalius (De humani corporis fabrica VII, beginning, 1543 edition, p. 605).

The Jesuit Rogerius Josephus Boscovicius (1711-1787) from Ragusa (modern Dubrovnik) invented the Boscovich curve, with which he proposed a unified physical force for all matter. He conceived it as a complicated mathematical function (see fig. 25), described in Theoria philosophiae naturalis redacta ad unicam legem virium in natura existentium (1763 edition, p. 16) thus:

materiam constantem punctis prorsus simplicibus, indivisibilibus, \& inextensis, ac a se invicem distantibus, quæ puncta habeant singula vim inertiæ, \& præterea vim activam mutuam pen- 
dentem a distantiis, ut nimirum, data distantia, detur \& magnitudo, \& directio vis ipsius, mutata autem distantia, mutetur vis ipsa, quæ, imminuta distantia in infinitum, sit repulsiva, \& quidem excrescens in infinitum: aucta autem distantia, minuatur, evanescat, mutetur in attractivam crescentem primo, tum decrescentem, evanescentem, abeuntem iterum in repulsivam, idque per multas vices, donec demum in majoribus distantiis abeat in attractivam decrescentem ad sensum in ratione reciproca duplicata distantiarum.

'that matter is unchangeable, and consists of points that are perfectly simple, indivisible, of no extent, and separated from one another; that each of these points has a property of inertia, and in addition a mutual active force depending on the distance in such a way that, if the distance is given, both the magnitude and the direction of this force are given; but if the distance is altered, so also is the force altered; and if the distance is diminished indefinitely, the force is repulsive, and in fact increases indefinitely; whilst if the distance is increased, the force will be diminished, vanish, be changed to an attractive force that first of all increases, then decreases, vanishes, is again turned into a repulsive force, and so on many times over; until at greater distances it finally becomes an attractive force that decreases approximately in the inverse ratio of the square of the distances. ${ }^{60}$ (Trans. Child, p. 17)

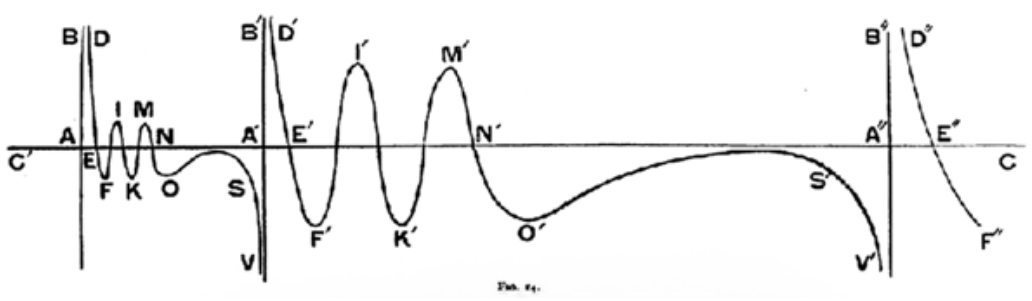

Fig. 25: One of several representations of the Boscovich curve by Boscovich himself (Theoria philosophiae naturalis, ed. Child, p. 137).

This is a complicated sentence (containing four ablativi absoluti) describing a complicated function. This Jesuit author was another advocate of using 'good' Latin in the sciences - possibly a reason why he has largely been neglected and is today little known despite the obvious importance of his ideas. ${ }^{61}$ There were many outstanding scholars and poets among the Jesuits of Ragusa, all still writing in Latin. For instance, the poet Benedictus Stay (1714-1801) wrote hexametric poems on the history of philosophy (mentioned in chap. $5 \S 2$ above); he was a friend and pupil of Boscovich.

60 Thus, Boscovich intended to see Newtonian gravity only as approximately correct, like Einsteinian relativity does today.

61 Ullmaier (2005) tried to change this. 


\section{The revolution's Latin}

§5 Latin was still the near-exclusive medium of communication, at least if the content was meant to be received internationally. Only some first conclusions about these texts' Latinity can be offered, as preliminary studies are missing. ${ }^{62} \mathrm{Re}-$ cently, the Neo-Latin language in general has finally begun to receive more attention. The trend seems to be that it was much less static and 'classical' than was previously thought, even in the belles-lettres. Helander studied Neo-Latin neologisms and found an 'eclectic attitude' (2014: 39). This does not differ much from scholastic practice, with the possible exception that Greek coinings became more frequent and were now nearly always formed correctly. Obviously, this is a consequence of a much more common and thorough learning of Greek after the Renaissance. ${ }^{63}$ Neologisms of non-Greek origin can still be found, especially Germanic and Arabic, as in mediaeval times, but their numbers would seem to decrease. Among Latin internal means of forming new words, the suffixes for denoting qualities (-tas, chap. 11 §2) and processes (-tio), encountered above as being conspicuous in scholastic Latin, are still very dominant (Helander 2014: 43). The typically scholastic nominal style is still often found in scientific Neo-Latin, where one finds rather

\section{Respiratio fit cum pectoris et sterni contractione}

'Breathing happens with contraction of the chest and the breast-bone'

than

respirant et eodem tempore pectus et sternum contrahuntur,

which would be rhetorically superior; 'factual texts differ considerably from the ethos of ancient oratory and historiography' (Helander 2014: 45). Such suffixes will be part of the corpus studies below (chap. 18 §). The Latin of the authors presented above is very far from uniform. Some of them actively worked on their language. Vesalius consciously used Latin names for the different parts of the body, which before him either had no name or only a Greek one. In general, Vesalius is unusual among these authors in striving to write a rhetorical, humanist Latin ${ }^{64}$ -

62 Ogilvie (2015: 264) may somewhat overemphasise the success of the humanist movement in changing university Latin, as we shall see.

63 Some examples in Helander (2014: 40-41), who stresses that this procedure was especially common in medicine and biology.

64 See Korenjak (2016: 248). Olschki (1919-1927) praises Vesalius’ Latin: 'Erasmus der Medizin' (2:95), says more about his classicist syntax (99), and comments on the 'Paarung vom neuen Forschergeist und antiquarischer Bildung' ('combination of the new spirit of research and antiquarian education'; 101). 
one that apparently was too difficult for some of his students, for easier réécritures were circulating. ${ }^{65}$ Boscovich can be added to this group of 'humanist' scientists. In contrast, Fuchs's Latin looks very pedestrian and mediaeval; that of Leibniz often looks rather more scholastic than he himself would be happy to admit. The Latin of these authors differs widely, but even the Latin within their works often differs strongly, depending on the part of the work. Paratexts such as dedications and introductions are often written in more humanistic Latin; the scientific core of the work is usually in technical Latin without much concern for the beauty of language. Despite these many differences, there are still not only external common features - such as a stricter methodology and terminology, better communication among scientists, and a much wider audience interested in new approaches but also some linguistic points that unite the authors. It would seem that early authors such as Fuchs and Vesalius were atypical. Seventeenth-century scientific authors' Latin seems to be more uniform: we might speak of academic Latin largely based on scholastic Latin but enriched with humanist and mathematical features; frequent Greek quotations can be counted among the former. Like scholastic Latin, this was a truly international form of communicating; regional peculiarities are hardly ever found. This academic Latin will remain in use up to the twentieth century in some cases (chap. 15). Its manifestations encountered in the text samples above may display a more Euclidean Latin (Newton) contrasting with a more scholastic type of writing (Leibniz). As touched upon already above (chap. 12 §), in some sciences there is indeed a more marked change of style around the sixteenth century: toward a mathematical Euclidean Latin (see chap. 22). In some others, such as medicine, there is hardly any noticeable change (chap. 21). In fields in proximity to the humanists, a more pretentious style was now expected, for instance in philology and linguistics. Below (chap. 18), a text by the German philologist Heinrich Kretschmann (1844-after 1910) on Apuleius' Latin is used as an example of late philological academic Latin.

\section{Comparison of Kircher and Newton}

\$6 From the foregoing, it will have become clear that in the seventeenth century several competing scientific approaches or paradigms coexisted and it was hardly clear which one would become the paradigm for the centuries to come: from mathematical theologies, rationalists, and hermeticists to experimentalist magicians, all treated in this and the previous chapters. Thus, the situation can be compared to that of the twelfth century: we can speak of different sub-Denkstile

65 See Olschki (1919-1927: 2:99). 
(as the main scientific Greek approaches remained intact). Two of the main competitors can be compared using their most famous exponents: Kircher and Newton, who can be taken to stand for a more hermetic-holistic as opposed to a mathematical-empirical approach. The two men actually had much in common: both were interested in theology, human, and natural science, and both were seen as geniuses in their time. Kircher published in many fields, but Newton during his lifetime only in physics, where he had lasting success. For their approach to physics, a comparison between the Principia mathematica and Kircher's Magnes sive de arte magnetica (Romae, 1641) is illuminating. Kircher uses a similar structure as Newton: there are experimenta, propositiones, theoremata, consectaria (i.e. corollaria). But besides the occasional elementary geometry, there is no mathematical approach at all. In contrast, Newton made frequent use of geometry, occasionally hinting at calculus. Another obvious difference is that Kircher has a tendency to digress - for instance about thermometers, thermoscopia (586) - whereas Newton is more to the point; his magnum opus in its Euclidean terseness is, indeed, hard reading. Despite this very technical nature of Newton's text, the main idea, the three Newtonian laws of gravity, can be summarised on half a page. In his Principia, Newton speaks only about physics, ${ }^{66}$ Kircher in his Magnes ends with a rather poetic digression on God as the ultimate magnet (Deus opt. max. totius naturae magnes; p. 907). This holistic approach may be typical of universalist 'hermetic' science. Wagner (2011: 12-16) compares what she calls 'hermetic' and 'mechanistic' worldviews that were competing in the sixteenth and seventeenth centuries: toward the end of this period, the latter clearly gets the upper hand; for this, Newton's Principia will have been crucial. Some of her distinctions can be summarised in the form of a table:

\begin{tabular}{l|l|l}
\hline Topic & Hermetic & Mechanistic \\
\hline matter & continuous, homogenic, featureless & atoms plus vacuum \\
\hline (primary) qualities & $\begin{array}{l}\text { exist in their own right; four } \\
\text { elements, hot/cold }\end{array}$ & $\begin{array}{l}\text { depend on atoms (thus, quality } \\
\text { becomes quantitative) }\end{array}$ \\
\hline causality & magia naturalis with sympathies & only through colliding atoms \\
\hline nature & $\begin{array}{l}\text { holistic: nature as organism, alive, } \\
\text { divine, correspondence between } \\
\text { different strata of being }\end{array}$ & $\begin{array}{l}\text { nature as mechanical, not alive, not } \\
\text { divine, only made by God, local } \\
\text { interaction only }\end{array}$ \\
\hline
\end{tabular}

66 Excepting the famous scholium generale, first added to the work in the second edition of 1713 (https://www.e-rara.ch/zut/wihibe/content/titleinfo/338618). Here Newton discusses 'hypotheses' and theology. This text is short (481-484) and remains more an appendix than an integral part of the work itself. 
This 'hermeticism' is largely based on neo-Platonism, which in turn had taken over Aristotelian methodology and terminology. The 'mechanistic' worldview is also indebted to Antiquity, especially Democritus and later atomists, but also Plato's Timaeus; the terminology is less Aristotelian, the rôle of mathematics and of Euclid is more central. Klein (2018: 211, shortened) has published a similar table but one that concentrates more on external factors. Kircher would still count among 'vormoderne Wissenschaft', Newton among 'moderne Wissenschaft':

\begin{tabular}{l|l|l}
\hline & $\begin{array}{l}\text { Vormoderne Wissenschaft } \\
\text { (sprachfundiert) }\end{array}$ & $\begin{array}{l}\text { Moderne Wissenschaft } \\
\text { (zahlenbasiert) }\end{array}$ \\
\hline Prototypischer Zugang & $\begin{array}{l}\text { qualitativ-sprachlich } \\
\text { (Substanzbegriff) }\end{array}$ & $\begin{array}{l}\text { quantitativ-mathematisch } \\
\text { (Funktionsbegriff) }\end{array}$ \\
\hline Basiseinheit & Wort, Satz, Text & Zahl, Formel, Tabelle \\
\hline Basisaktivität & lesen, schreiben, interpretieren & $\begin{array}{l}\text { rechnen, messen, beobachten, } \\
\text { experimentieren }\end{array}$ \\
\hline Prototypischer Ort & Bibliothek, Lesesaal & Labor, Natur \\
\hline Fakultäten/Leitdisziplin & $\begin{array}{l}\text { Theologie, Medizin, Jura, } \\
\text { Philologie }\end{array}$ & $\begin{array}{l}\text { Naturwissenschaft (v.a. Physik, } \\
\text { Chemie), Mathematik }\end{array}$ \\
\hline
\end{tabular}

Several traditional sciences had to undergo considerable adaptations in order to move from the former worldview to the latter and be integrated into the 'New Science'. Physics becomes quantitative, alchemy changes into chemistry, ${ }^{67}$ astrology drops out completely. Positing two such types of science is conceptually interesting, but it should be kept in mind that most authors discussed above do not fit fully into one or the other: many of the protagonists of this paradigm shift in the natural sciences inhabited both worlds without reflecting on it at all. Newton the alchemist belongs to the former, Newton the physicist to the latter (although he does implement non-corpuscular 'force' with huge success). ${ }^{68}$ And already in the eighteenth century, there were approaches that are hard to group into one of these two approaches, such as that of Boscovich, whose physical theory is based on an all-pervasive mathematical force that acts on point particles in varying strength depending on their distances, a theory that clearly grew out of

67 See Newman \& Principe (1998), who point out that the two terms are synonymous before the eighteenth century. The important point here is that only the component of alchemy/chemistry that is compatible with the New Science remains as an acknowledged 'science'; it is eventually termed 'chemistry' in contrast to the rest ('alchemy').

68 More on Newton in this respect in Wagner (2011: part 3); Burtt (1954). 
Newton's gravity yet contains elements of a 'hermetic' kind such as a holistic approach and its featureless point-atoms. Clearly, this dichotomy of old versus new science is only a rough template for a first look at reality that is more complex. In addition, it seems to have been confined to the natural sciences: although the revolutionary period brought many advances in the human, legal, and historical sciences (some mentioned in the list above), they were much more gradual and they do not fit into either of the tables.

Worse still, the victory of the mechanic worldview was not lasting. More and more features of what would seem to be typically 'hermetic' or universalist have returned to reputable sciences. ${ }^{69}$ For instance, far distant systems can now be linked by 'quantum entaglement'. Traditional geometry, the key to science for Galileo and Newton, has in the meantime been transformed into the study of relations within mathematical groups. ${ }^{70}$ It has moved very far fom Euclid, now studying things like the exactly seventeen wallpaper symmetry groups on the Euclidean plane (depicted in fig. 26); ${ }^{71}$ this looks more like a Kircherian illustration than traditional Euclidean geometry. It would seem that a new revolution in the late nineteenth and in the twentieth centuries definitely reversed the victory of the mechanistic worldview, which was based on what is now seen as elementary Euclidean geometry. Today, even in physics the essential constituents are fields and forces that act at a distance, not atomic Lucretian corpuscles; the latter are seen as mere epiphenomena. It would seem that this Lucretian approach became so successful in the seventeenth century mainly due to the advances in mathematics, especially calculus, that enabled scientists to describe such phenomena quantitatively, something completely out of reach for Democritus or Lucretius. Although this mechanical atom-and-void approach made 'occult' interaction at a distance (important, for instance, in astrology) impossible, it proved to be too rigid: Newton's theory of gravity again introduces interaction at a distance, but with the important novelty that this interaction follows precise mathematical laws.

69 Of course, other things, such as the hot/cold qualities or the four elements, have been discarded for good by more advanced theories.

70 Especially by Felix Klein's Erlangen Programme; see Klein (1872).

71 Each of these patterns is invariant to some combination of Euclidean isometries (translations, rotations, reflections, and glide reflections). It was proved in 1891 that there are exactly seventeen such groups in the Euclidean plane. 


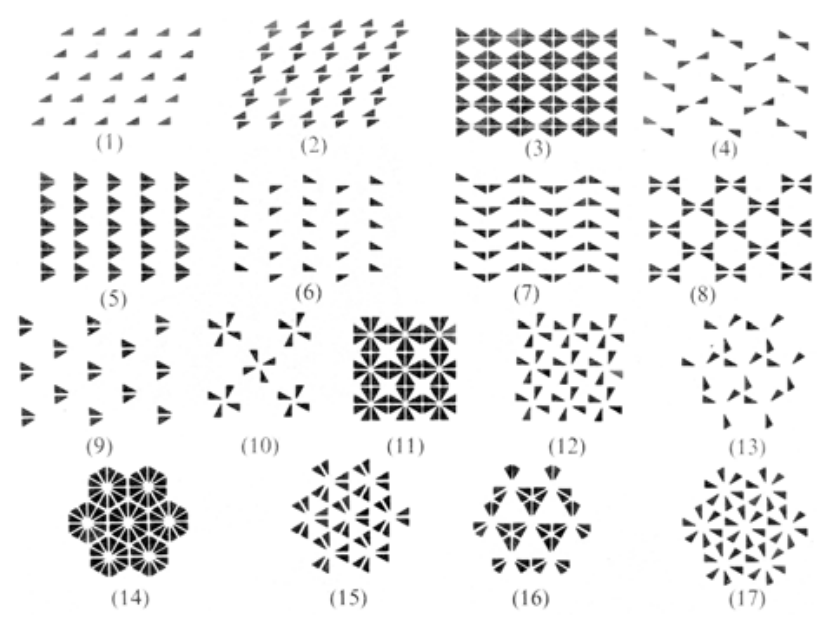

Fig. 26: The seventeen wallpaper groups, from Mainzer (1988: 151).

Since Kuhn it has become common knowledge that there is a revolutionary moment in science in general. For Latin science, the great revolution happens in the twelfth century with the advent of the Greek scientific Denkstil and the radical transformation of Roman and mediaeval science. That this change is not usually called a 'scientific revolution' will have to do with the fact that Latin science largely digested already existing Greek science during the twelfth century, in contrast to the seventeenth century, when completely new kinds of science developed. A final caveat about the validity of speaking of the Scientific Revolution seems necessary. After the so-called Sattelzeit (ca. 1750-1850) ${ }^{72}$ that changed Europe, and with it the world, fundamentally, the greatest revolution in science started in the late nineteenth century and has not yet finished. This period stopped using Latin as a central vehicle for scientific communication (and is therefore outside the scope of this book) but has seen by far the greatest number of people working as professional scientists. Very important conceptual novelties have revolutionised many sciences and produced entirely new ones: some of the most important instances may be the concept of evolution in nature (famously with Charles Darwin, but also many others such as August Schleicher for language), new approaches to physics (quantum theory, relativity) and to mathematics (new foundations of set theory, including its paradoxes; chaotic systems), the invention of biochemistry, linking 'dead' and 'alive' matter, and the recent great advances in information theory. Statistical tools enable a new kind of pre-

72 This term is from Koselleck (1972). 
cision for things that do not always behave the same way; they have recently produced the replication crisis (Ioannidis 2005). Together, these things have turned early eighteenth-century science as much upside down as it did Aristotelian science. Thus, the Scientific Revolution may have to be renamed the 'First Scientific Revolution'. ${ }^{73}$

\section{Relation to criteria for science}

\$8 Although the 'Scientific Revolution' produced many different methods and approaches, there was definitely a general focus on methodology and on systematically searching out new phenomena in many fields (I and II). In the extreme case, in the mechanistic worldview only impacts between atoms were allowed as explanatory. Some things could be explained step-by-step very well, such as gravity (Newton) or blood circulation (Harvey). In this time, experimentation becomes central, and with it the criterion of testability is often more strongly satisfied than before (III). Some approaches (such as the mechanistic one) presented a coherent explanation for everything (IV). In these times, community efforts are also strengthened (V) and many sciences become more formalised, be it through mathematical (such as physics) or other means (such as Linnaeus' nomenclature of organisms; VI).

Thus, it will not come as much of a surprise that the criteria for science are well fulfilled in the age of the 'Scientific Revolution'. Of course, appropriate methodology was much discussed, and much of it has been changed in the meantime: for instance, no one today shares a purely mechanistic worldview any more. However, as already hinted at, the demarcation between 'Scientific Revolution' science, hermeticist science, neo-Platonist science, and other forms of trying to reach insight was not at all clear at the time. It only seems clear to us in retrospect, and quite an amount of hagiography has been produced for some of the most important exponents of the 'Revolution', such as Galileo and Newton. We have seen (§3) that even Newton lived in at least three intellectual worlds: those of the physicist, the (heretical) theologian, and the hermeticist alchemist. More or less at the same time, both the 'Scientific Revolution' and the general international use of Latin in science and scholarship come to a close in the eighteenth century. The next chapter describes this process and will then try to find some reasons for why it happened, and why it happened then.

73 Vol. 8 of the Petruccioli (2001-2004) encyclopaedia, indeed, aptly bears the title La seconda rivoluzione scientifica for this time. 